\title{
THE AGENCY SEARCH: THE MEANING OF WORK FOR APP DRIVERS
}

\author{
MARCIA C. VACLAVIK ${ }^{1}$ \\ (iD) https://orcid.org/0000-0003-4209-1054 \\ LIANA H. PITHAN ${ }^{1}$ \\ (iD) https://orcid.org/0000-0002-2251-0242
}

To cite this paper: Vaclavik, M. C., \& Pithan, L. H. (2018). The agency search: The meaning of work for app drivers. Revista de Administração Mackenzie, 19(5). doi:10.1590/1678-6971/eRAMG180080

Submission: Apr. 30, 2018. Acceptance: July 16, 2018.

Universidade Federal do Rio Grande do Sul (UFRGS), Porto Alegre, RS, Brazil.

\footnotetext{
(cc) BY 


\section{ABSTRACT}

Purpose: This study aims to investigate how app drivers are giving meaning to their work, taking as a theoretical assumption the model proposed by Rosso, Dekas, \& Wrzesniewski (2010).

Originality/value: Internationally, the volume of empirical research involving digital labor markets is considered to be low. Nationally, research in the context of Sharing Economy rarely focuses on the labor perspective. Despite being a growing phenomenon, no studies were found on the production of meanings and meaningfulness of work by app drivers.

Design/methodology/approach: This qualitative and exploratory research was carried out with 37 app drivers between May and September 2017, in Porto Alegre (RS, Brazil). Randomly selected, respondents were called to a work route by the transport application. The interviews' content was categorized and analyzed according to the framework of Rosso et al. (2010).

Findings: Elements that refer to all the model quadrants were found: "self-connection", "individuation", "contribution", and "unification". The predominant meaning, however, is desire, seeking and valuing by the agency, in the mechanisms of self-efficacy and self-management, especially in the financial, autonomy and flexibility perspectives. This research contributes to the intersection of the study of the labor world transformations and the construction of meanings and meaningfulness, using a framework little used in Brazilian research. It also collaborates to broaden the understanding of digital labor markets, especially their impact on workers.

\section{KEYWORDS}

Meaning and meaningfulness of work. Sharing economy. Digital labor markets. Gig Economy. App drivers. 


\section{INTRODUCTION}

Technology has revolutionized and continues to revolutionize the way people live, work and communicate (Eurofound and the International Labour Office, 2017). In a context that is increasingly digital, global, diverse and integrated with social media (Deloitte, 2017), challenges and opportunities across the social, economic, political and cultural spheres, imposing themselves on organizations, institutions, and individuals. If there is a kind of "technological imperative" that forces changes, one must understand its interactions with the world of work, in which new relationships are designed in a progressively connected environment.

Driven by increased environmental awareness and reduced preference for ownership over use/access, by maximizing the utility of underutilized resources (Botsman \& Rogers, 2011), the emergence and rapid rise of the Sharing Economy (SE), and the so-called Gig Economy (GE) seems to be a sign of further change. Movements that profoundly affect and modify labor relations (LRs) and may become prevalent in this century are underway (Balaram, Warden, \& Wallace-Stephens, 2017, Codagnone, Abadie, \& Biagi, 2016; Sundararajan, 2016).

Digital technological advancement, with the spread of the internet and smartphones, is strengthening the expansion of digital labor markets (DLMs), in which consumers and workers are mediate by online platforms, changing the traditional employer-employee relationship contributing to a further significant change in working patterns (Brescia, 2016; Carr, Hall, Mason, \& Varney, 2017; Coyle, 2017; Donini, Forlivesi, Rota, \& Tullini, 2017; Findlay \& Thompson, 2017; Fleming, 2017; Graham \& Shaw, 2017; Nyombi, 2015; Todolí-Signes, 2017).

In Brazil, the phenomenon gained visibility in 2014, with the entry of a North American platform in the mediation of passenger transportation through private cars. Currently, there are several companies of this kind, which make the country one of the largest markets in the world. As in the rest of the world, economic and judicial disputes thrive, which raises theoretical and practical concerns about the model's implications for the economy and the world of work (Cherry, 2016; Codagone, Abadie, \& Biagi, 2016).

In this context, this article aims to investigate how app drivers are giving meaning to their work, taking as a theoretical assumption the model proposed by Rosso et al. (2010). It is understood that, even in the contemporary conjuncture of transformations, work remains central to the workers, both psychologically and sociologically (Tolfo \& Piccinini, 2007). It is also 
understood that studying LRs implies acknowledging their dynamism (Concolatto \& Oltramari, 2017), so that the ambiguities and complexities adjacent to the work cannot be ignored: at the same time, associated with suffering, it can express compulsory physical activity, a torturous and sacrificial obligation that serves only for the survival and acquisition of goods, it may also be associated with autonomy as a creative activity, source of safety, satisfaction, fulfillment and emotional, ethical and cognitive development (Baldry et al., 2007; Kovács, 2002; Tolfo \& Piccinini, 2007).

Considering Brazilian research on meaning and meaningfulness of work, there is the prevalence of empirical research that has recently investigated the meaning of work from occupations such as: criminal experts (Rodrigues, Barrichello, Irigaray, Soares, \& Morin, 2017); penitentiary agents (Siqueira, Silva, \& Angnes, 2017); military officers (Benevides, Almeida, Cunha, \& Mendes, 2014), university professors (Boas \& Morin, 2016; Nascimento, Costa, Salvá, Moura, \& Simão, 2016); nursing professionals (Rodrigues, Barrichello, \& Morin, 2016) and workers of tapioca flour factories (Pinto, Paula, Lobato, \& Vilas Boas, 2015).

There are also studies on prostitutes (Silva, Borges, Mafra, \& Cappelle, 2013; Silva \& Cappelle, 2015; 2017); employees who became entrepreneurs (Lemos, Cavazotte, \& Souza, 2017); voluntary work (Borchardt \& Bianco, 2016) and fired and rehired workers (Campos \& Saraiva, 2014). Also noteworthy is the work by Silva and Simões (2015), who see the importance of the subject for the management of people in organizations, and Rohm and Lopes (2015), who critically analyze the production of meaning from the managerial logic and focused on organizations.

However, recent national studies on the subject did not address the most contemporary labor relations (technology-mediated) and did not focus on the traditional employer-employee relationship. Moreover, in a bibliometric study of Brazilian production on meaning and meaningfulness of work, Spinelli-de-Sá and Lemos (2015) observe the prevalence of studies based on the $\mathrm{MOW}^{2}$ studies, so that there are still ways to be explored.

Internationally, Rosso et al. (2010) show, despite the long academic tradition of the subject, the fragility of isolated analyses, from single and simplistic sources of how people construct the meaning and meaningfulness

The Meaning of Work (MOW) International Research Team (1987) investigated the different definitions and meanings of work, through international research with more than 14,700 people in eight countries. The MOW divided the structure of the concept of meaning of work into three domains: the centrality of work, the societal norms of work and the valued results and goals of work (Spinelli-de-Sá \& Lemos, 2015). 
of work. According to the authors, it is urgent to realize that there are multiple possible sources that are interrelated, causing additive effects and even multipliers through this interaction. It is salutary, therefore, to understand the meaning and meaningfulness of work in a multidisciplinary, multidimensional and dynamic perspective, resulting from the interaction of personal and environmental variables related to work (Tolfo \& Piccinini, 2007).

Thus, to understand how the individuals involved in activities linked to the context of digital labor markets are experiencing and giving meaning to this process can help in understanding the phenomenon. Since the low volume of empirical research involving digital labor markets is recognized as a problem of great importance (Codagnone, Abadie, \& Biagi, 2016; Donovan, Bradley, \& Shimabukuro, 2016), broadening the comprehension of the realities of these workers can contribute to better comprehend the phenomenon to which this article intends to bring contributions.

After all, it has been more than ten years that Baldry et al. (2007) pointed out that the vast literature of predictions about the future of labor is rarely based on empirical research, a fact that is considered a relevant gap. Thus, research on a context still under construction shows an opportunity still unexplored by researchers, a scientific need and a great challenge (Codagnone, Abadi, \& Biagi, 2016; Coyle, 2017), still needing to be expanded and deepened (De-Stefano, 2017).

In the next chapters, we present the theoretical framework that addresses issues related to work in the new emerging economic models, as well as discusses the conceptual aspects about the meaning of work through the presentation of the theoretical model adopted in this research. In continuation, the methodological path covered is explained and the results of this research, together with the analysis and the discussion, are presented. In conclusion, the contributions, the limitations and the suggestions of future studies are presented in the final chapter.

\section{NEW ECONOMIES AND WORK IN MUTATION}

Discussions about work often associate it with "change" and "transformation" (Cacciamali, Ribeiro, \& Macambira, 2011; Cattani, 2014; Kovács, 2002; Mocelin, 2015). It is necessary, therefore, to understand it from the historical context, since "the patterns that shape the LRs. . . are flexible and are changing as society itself changes" (Concolatto \& Oltramari, 2017 , p. 7). Faced with this process, there are gaps in the adaptation of 
technological instances, individuals, organizations and the public sphere (Deloitte, 2017), which reinforces the need to understand them relationally.

Discussions about work, therefore, can only be fully understood if analyzed in broad socioeconomic contexts, since economic activity is organized in different formats and with a diverse range of employment contracts, pointing to a greater versatility of labor organization (Baldry et al., 2007). As Fleming (2017, p. 695) points out, "flexibility is perhaps the most common term to describe employment today".

It is perceived that SE and GE, interlocking phenomena, are shaping new ways of working (Donini et al., 2017), changing the existing labor standards (Balaram et al., 2017; Coyle, 2017) and contributing to the development of DLMs. ${ }^{3}$ Thus, understanding these movements only from the point of view of technology or consumption represents a misunderstanding, because it overlooks work as a fundamental element (Codagnone, Biagi, \& Abadie, 2016).

It is not a simple task, however, to characterize the workforce of SE and GE (Codagnone, Abadie, \& Biagi, 2016; Donovan et al., 2016; Todolí-Signes, 2017). Terms such as "micro-entrepreneurs", "self-employed", "freelancer", "on-demand workers", "independent workers", among others, are used in reference to those involved in activities involving work in that context.

Such terminological confusion may lie in the fact that these new models of work, fully linked to the changes brought about by accelerated technological development, are strongly associated with the appeal to freedom and autonomy. Indeed, in this new way of exercising labor, these workers can experience flexibility at a much higher level than traditional workers (Cherry, 2016), both in determining their schedules and in the absence of hierarchy, operating directly to the demanding market through of digital mediation.

These characteristics, coupled with the understanding that gig workers are fully responsible not only for making the tools and materials available but also for the costs and risks associated with them, facilitates an approach to the entrepreneurial activity-idea contained in most of the terms used to define this new worker model.

In order to analyze the labor activity in this perspective, linking it to the examination of meaning and meaningfulness, it is necessary to return to the idea of deprivation associated with the work of employees since industrialization, when the work routine was given by the imposition of

As an initial definition for DLMs, it is the idea of the labor market: an abstract place that brings together the set of job offers and demands (Rocha-de-Oliveira \& Piccinini, 2011), now digitally mediated (Codagnone, Abadie et al., 2016). 
control and rarely by consent (Baldry et al., 2007). Thus, if on one hand the execution of labor tasks provides a more intrinsic reward, the greater the control of the individual over all work, on the other hand, the notions of "control" and "consent" are reedited through time and in different contexts. In this way, self-employment in DLMs would, from an optimistic perspective, have the potential to confer on the individual self-control and self-consent, in which voluntarism would eliminate the idea of personal deprivation associated with work.

Faced with the information technologies that characterize the DLMs, the old bureaucratic control commands are anachronistic, replaced by the horizontal interaction between committed and self-motivated workers who cooperate in flattened structures. In this environment, transformations in the world of workforce adaptation to self-management of the career, now outside the organizational environment, where the worker is expected to make adjustments in a proactive and self-responsible manner, while labor and career patterns emerge less organized, are fueled by personal preferences and efforts (Baldry et al., 2007).

It should be stressed that the independent or non-standardized workcharacteristic of DLMs-is not a recent phenomenon (Kovács, 2006). However, it is necessary to expand the understanding of the expansion of this work, now mediated by digital platforms, and its effects on workers and on the labor market itself-that is new and lacking in understanding, given that the high growth rates of platforms and rapid adherence to the model suggest that "we are only beginning to see their impacts" (Manyika et al., 2016, p. VIII).

\section{MEANING AND MEANINGFULNESS OF WORK}

Although meaning and meaningfulness of work appear as synonyms in most national academic research, Bendassolli and Gondim (2014) emphasize the importance of understanding them distinctly but considering the interrelationship between the two orientations as parts of the same construct. The authors understand meaning as a process of subjective individual construction, changeable, linked to affective processes and accessed by biography and narratives, and meaningfulness as a socially shared image or concept, marked by a level of generalization of signs on a given object. The authors propose the concept of the psychological function of work as an articulator that integrates meaning and meaningfulness in the constitution 
of the subject in relation to the world. In line, Pereira and Tolfo (2016); Tolfo and Piccinini (2007) and Tolfo, Coutinho, Almeida, Baasch, and Cugnier (2005), in turn, consider that meaningfulness is a construct built collectively in a given historical, economic and social context, and the meaning is conceived as a personal production, in function of the individual understanding of the collective meanings of everyday experiences. In addition to being interdependent, meaning and meaningfulness are transformed into a dialectical relationship with reality.

Admitting the lack of consensus between meaning and meaningfulness, Steger, Dik, and Duffy (2012) adopt the expression "meaningful work", arguing that studies do not focus on what work means for people, but how work is meaningful and positive in valence. The positive valence of meaningful work, they claim, has a eudaimonic focus (growth-and purpose-oriented) rather than hedonic (pleasure-oriented).

For Rosso et al. (2010, p. 94), the interchangeable use of meaning and meaningfulness contributes to confusion about these constructs. According to the authors, the meaning is how an individual interprets what their work represents or plays in the context of their life. Part of the psychological perspective is elaborated individually and influenced by the environment. It can be positive, negative or neutral. Meaningfulness, in turn, refers to the amount of significance of something to an individual: the more the work is experienced as meaningful, the more positive the experience is. According to them, authors often use the constructs in an exchanged form.

Thus, in this article, the conceptual model proposed by Rosso et al. (2010) is adopted. The authors provide an integrative theoretical framework (Figure 3.1), organized from the cross-over of the four key dimensions of sources and mechanisms of significance: the vertical dimension of agency-communion indicates that while some emphasize desire and the search for agency, others emphasize desire and the quest for communion; and the horizontal dimension, self-others, which points to the variation of the perception of the significance of the work once the action is directed to oneself or to the others. The agency-communion dimension refers to the motivation of action, while the self-others dimension is directed to the target. The sources of meaning of work can be analyzed from four axes: the individual (values, motivations, beliefs and their self-definition from which to orient themselves in relation to work); others (colleagues, leaders, community, family); the work context (outline of tasks, organizational mission, financial circumstance, domains of non-work, national culture); and spiritual life (spirituality, work as a vocation). 
At the intersections between the key dimensions, there are four possibilities from which meaningful work is created or maintained: selfconnection (self-communion intersection: meaningfulness from actions that align individuals with the way they see themselves); individuation (self-agency intersection: meaningfulness from the establishment of the self as a valuable and autonomous individual); contribution (others-agency intersection: meaningfulness from the perception of actions at the service of others); and unification (others-communion intersection: meaningfulness from actions that lead to communion and harmony with other people or principles) (Allan, Autin, \& Duffy, 2014; Rosso et al., 2010).

\section{(Figure 3.1)}

\section{THEORETICAL FRAMEWORK FOR MEANINGFUL WORK}

\begin{tabular}{|c|c|c|c|}
\hline \multicolumn{4}{|c|}{$\begin{array}{l}\text { Agency } \\
\text { (drive to differentiate, separate, assert, expand, master, and create) }\end{array}$} \\
\hline \multirow{9}{*}{ Self } & Individuation & Contribution & \multirow{9}{*}{ Others } \\
\hline & Self-efficacy: control/autonomy & Self-efficacy: perceived impact & \\
\hline & Self-efficacy: competence & Purpose: significance & \\
\hline & Self-esteem & Transcendence: interconnection & \\
\hline & & Transcendence: self-abnegation & \\
\hline & Self-Connection & Unification & \\
\hline & Authenticity: self-concordance & Purpose: value systems & \\
\hline & Authenticity: identity affirmation & Belongingness: social identification & \\
\hline & Authenticity: personal engagement & Belongingness: interpersonal & \\
\hline
\end{tabular}

Communion

(drive to contact, attach, connect, and unite)

Source: Elaborated by the authors based on Rosso et al. (2010, p. 114).

In the quadrants, the authors arranged the 13 mechanisms of construction of the meaningful work, namely: authenticity by self-concordance, by affirmation of identity or by personal engagement, in the category selfconnection; self-esteem and self-efficacy by control/autonomy or by competence, in the quadrant individuation; self-efficacy by perceived impact, purpose by significance and transcendence by interconnection or by self-abnegation, in the category contribution; belonging by social identification or by interpersonal connectivity and purpose by value system, in the quadrant unification. 
Although conceptually distinct, dimensions are not considered mutually exclusive. The authors understand that more than one pathway can be activated simultaneously, with additive or interactive effects (Rosso et al., 2010). In short, an understanding of meaningful work experience may arise from the execution of a work aligned with one's personal identity, helping one to feel valuable, involving harmony with others, and contributing to the common good (Allan et al., 2014).

\section{METHODOLOGICAL PROCEDURES}

Given that the object of this research is a recent phenomenon (as discussed in previous sections) and that it is still in the consolidation phase (with many changes in the economic and legal scenario), it was decided to outline it qualitatively (Flick, 2009), under the exploratory approach. Such a choice is based on Gil (2010), who explains that this perspective is indicated to improve or unveil ideas and research possibilities.

Thus, 37 interviews were conducted with app drivers between May and September 2017, in the city of Porto Alegre (RS, Brazil). Data collection was performed through semi-structured individual dialogues with open questions. The respondents were randomly selected, called to a work route by the private passenger transport application engine and invited to discuss the questions proposed by the researchers in their own work environment. From the willingness of the drivers to speak, the interviews were recorded and later transcribed, to which field notes were added with observations of the researchers, resulting in the corpus of analysis. In all, 33 men and four women were heard on routes that ran between 10 and 39 minutes.

The pre-analysis of the raw material (transcripts of the interviews and field notes) was carried out from the integral and individual reading by the authors, aiming to prepare the corpus for the following analytical steps. Following the precepts of completeness, homogeneity and pertinence (Bardin, 2016), the content was initially classified according to the 13 main mechanisms of construction of the meaningful work and then categorized according to the four quadrants in which these mechanisms are distributed in the theoretical proposition of Rosso et al. (2010): self-connection, individuation, contribution and unification. Under this categorization, therefore, the results are discussed and analyzed in the next section. 


\section{PRESENTATION AND ANALYSIS OF RESULTS}

In order to investigate how transport app drivers are giving meaning to their work, understanding the reasons that led them to join the activity and how they perceive themselves in a future projection can bring important contextual elements to the analysis. It is evident the heterogeneity of the field when, as regards the reasons for joining the activity of app driver, were cited: unemployment; disappointment with the formal labor market, whether due to low wages, pressure for results or lack of flexibility; the need for income supplementation; the disappointment with the previous entrepreneurial activity, mainly due to the behavior of the clients, the difficulties with the management of the business or with the teams; and the drop in income in taxi driver activity.

In addition, many respondents consider the activity temporary or transitory, making clear references to the abandonment of the craft in the future, since they have other perspectives (such as migrating from the area, opening a business or leaving the country). Others, however, say they intend to continue as drivers, but only as a complement to income, while few said they would continue to be app drivers as their main activity.

Analyzing the agency-communion dimension regards the motivation of action, the communion dimension appears especially related to the benefit that the service brings, both by the accessibility of the cost and by the end of the monopoly of the activity. As stated by Thiago, a former taxi driver, "nowadays, there are people that have never even got into a taxi and used Uber". Geron says that "this is good for everyone" because the taxis "were the big men on campus". Alexandre also highlights the positive aspect of the activity: "It's nice that you have this service available, more accessible today, right? It's really important to society, taxi drivers had this monopoly of control and ended up providing bad service, charging absurd rates". Rogério analyzes the impact of transport app from the perspective of high levels of unemployment in the country: "The app was great in this crisis! There were a lot of unemployed people who are working and generating money".

In this sense, although it is an aspect emphasized by a few respondents, it is possible to notice the existence of meaningfulness in the unification quadrant (communion-others intersection), especially from the mechanism of belonging by social identification (Rosso et al., 2010). However, it is not the result of the work of a driver that appears here, but rather the positive character of the activity, more broadly, from the perspective of the work 
context. The purpose mechanism is triggered by the realization that many drivers of the app now have higher yields than they did in their old jobs. "How many of them do you think earned this much before?" points out Sílvio, which is corroborated by the lines of Leandro, Sônia, and José.

In the quadrant of self-connection (self-communion intersection), Josiane's speech stands out, which sees in the occupation coherence with what she likes to do (authenticity as an affirmation of identity). "I love it! I was raised in this car thing, races, stock car, truck races. My mother told me that when I was little I said I wanted to be a taxi driver! Funny, isn't it? Impressive!" she said. Eduardo uses the same argument: "I think I was born for this! To ride on wheels! I wasn't born to be inside an office".

With the economic crisis that plagues the country, the market recession and low wages are used by many as justification for joining and staying in the activity, triggering mechanisms that support the engagement. Financially, according to Lucas, "you can earn more, perhaps, than the market is paying out there". Geron says he knows "people in high-ranked positions who have been dismissed from their companies. More than 20 years of company, and they now had a proposal again. One of them had a proposal to go back to the same company, but earning ridiculously less". Leonardo, a university student in management, reports that he would not be able to earn in a formal job the same he earns as an app driver: "Surely I wouldn't pay for my college, you know? For me, it was a great option. Only for college, I pay a thousand. In the labor market, how much would I earn? I don't know, a thousand, two thousand reais. For me, it's a good reason".

It is notorious, however, the predominance in the drivers' speeches in the agency dimension. In the individuation quadrant (self-agency intersection), one can see the importance given to the financial issue, referring to the activation of the mechanism of self-efficacy by control, as shown by the words of Paulo César, who emphasizes the resumption of the lifestyle lost with the low retirement wage: "I like to get my family together on weekends, have a barbecue"; Carlos ("I thank God I can make enough to pay for my car installments, I pay my bills, I pay pension, and I can pay the car"); and Juan ("We have to work right, when things tighten up, we have to, because the bills don't stop coming. . . it's like the tide on the beach"). Ildo, yawning, observes that "bills don't wait, so you can't choose not to work because you're tired". José, normalizing the practice of long shifts, says: "People who work 12, 15 hours a day have a good income, can make good money".

Still, in the individuation quadrant, where meaningfulness occurs in the establishment of the self as a valuable and autonomous individual 
(Rosso et al., 2010), mechanisms that refer to autonomy are widely used in the respondents' speeches. It is remarkable the desire for independence and freedom, so touted by proponents of the GE model. Geron states that the activity is "the best job in the world" regarding "freedom and income". "I've worked in an office, locked up, etc. I'd leave with my head exploding, I'd get very stressed and I almost didn't see the light of day. Indicators reports. . . the demand is very intense", he adds. Alexandre also emphasizes the feelings of autonomy and freedom. For him, the job as an app driver "is quiet", there is no need to present a medical certificate if you miss work, neither worry about it. "I made my schedule myself! ... It's compensatory. You can escape from that system, too: 'employee', having to clock-in, comply with a schedule", he adds.

The escape from the formal system provided by the activity is also said to be beneficial for Tanise, who resigned from a job in the area of Human Resources for being "pissed" of having to endure pressure for results and deliveries. Giovani values autonomy in everyday decisions: "I've seen a job where I depend on myself. . . I can work for myself and not work for others. I worked on a carrier and had to endure a lot, I had that fixed salary, but I had to give satisfaction as to where I went, what I was doing, who I was with. . . here I don't need to, so here I am independent". For his part, Guilherme celebrates freedom: "Just for not having a boss bothering you. . . I had a horrible boss! Not having a boss and earning more is great!", says the respondent.

With the desire for freedom being contrasted with the financial insecurity of the working model, great weight is given to self-responsibility for the gains. Giovani assumes the role of self-manager in affirming that "here I take care of my goals and I have my income", while self-demand is evidenced in Jeferson's statement: "Whoever wants to make money has to have a goal. I have my goals. I leave the house at one, when I drop the kid in school and start my shift. While I don't reach my goal, I don't go home".

Control, autonomy, and self-efficacy are clear in the idea that "the wage is on me", as Leonardo claims. "It's up to me to know how much I'm going to earn", he explains. João Vitor, when evaluating that "the work of a driver is good because it doesn't require schedule or attendance, you have no obligations", he does not perceive the contradiction in his own speech: "When we're not obliged it seems that we oblige ourselves more, right?". Carlos' ("If you don't work, you don't earn") and Vicente's ("If you produce, you earn, if you doesn't produce, you doesn't earn") remarks refer to the internalization of the worker's full accountability model, now manager of himself. 
In the last quadrant of the model by Rosso et al. (2010), the contribution (agency-other intersection) is perceived in the mechanism of transcendence by self-abnegation, especially the sacrifices made to family life, in the name of the family itself. Francisco, who went to work alone in his phone-delivery company after disappointing himself with his three employees, who were deceiving him, went on to supplement the income as an app driver for concern about family finances. His wife, a state school teacher who receives a salary in parcels, said he had "to get a job, so I came to this". Geron, for his part, would like to spend the weekends at home with his ten-month-old son, but there is no alternative "when the bills begin to pile up". Jeferson self-negotiates, with a financial perspective, when deciding to work on a Sunday, reducing the coexistence with his wife. No matter how bad it is, he says, Sunday is "the busiest day" and "the day that yields more money". Tanise demonstrates that it was from the moment she opted for the driver's activity that she became closer to her son: "Before, I didn't have time for him. He was having problems to learn how to use the potty, and after I started to have a more flexible schedule, things started to work out". The long shifts, mentioned by most of the respondents who have this activity as the main source of income, seem to be softened through the mechanisms of self-efficacy (perceived impact) and purpose.

In contrast to the contribution, some respondents explicitly reject personal contact in the name of work. Leonardo denied his girlfriend's request to end the shift earlier Friday night: "we don't see each other all week, we see little of each other, but I said: I'm sorry for you! Today I'm going to do these 25 [runs]". Ailson's daughter, who is eight years old and lives with her mother, wants her father's presence on weekends. "Then comes my daughter, talking my ears off. 'Dad, are you not going to stop for a while, so we can go to the mall?' What mall? Forget the mall! I'm out!” he says.

Another mechanism of this quadrant is triggered by the drivers: the interconnection. Eduardo, excited, compares the positive interaction he has with some passengers to a higher education course: "I'm attending college. . . in all the courses, whatever you imagine, I'm doing it, I'm embracing everything! I'm working with Cabify!” José also says he likes the activity because he gets to "talk to a lot of people", an aspect that is also highlighted by Artur: "Oh, I like it, it's cool, you meet a lot of people, good people, you talk. . . it's stressful to sit all day, driving, but it ends up being better than worse. There are more good things than bad things". For Vicente, the activity is "a remunerated therapy". To like the interaction with people is also emphasized by Jeferson, Edison, and Giovani, who value their work because "transporting people is a big responsibility". 
Regarding the sources of work meaning (Rosso et al., 2010), the above mentioned statements point to individual instances (especially those that mention motivations, beliefs and self-definition), of alterity (where the family appears quite present) and in the context of work (with emphasis on aspects related to economic and labor market crises and consequences for personal life). Another source of meaning, linked to the spiritual life, especially regarding the work as a vocation and referring to the centrality of work in life, is very present, as in Josiane's words ("I work, work, work. . . hard, hard!"), Édison's ("Why would I stay home sleeping? I'm going to work!"), João Vitor's ("If I don't work, it seems that something is missing from my day, I'm lost at home not knowing what to do") and Gabriel's ("I'm going to stay home doing what?").

From the elements highlighted in the respondents' speeches analyzed in the light of the framework proposed by Rosso et al. (2010), the next section proposes the discussion of the results, considering the context of the work impacted by the rise of the SE and GE models.

\section{DISCUSSION OF RESULTS}

A recent phenomenon that demonstrates a great capacity for growth (especially due to the adhesion facilitated by the low entry barriers, the economic crises and, consequently, the retraction of the formal labor market), the DLMs, from the expansion of the SE and GE, are attractive when settling under the positive perspective of flexibility and autonomy (Sundararajan, 2016). Murillo, Buckland, and Val (2017) also cite the positive aspects of SE from the viewpoint of a new work organization, now mediated by sophisticated algorithms that enhance flexible work opportunities that fit the convenience of workers.

In this study, the instrumental aspect (Andrade, Tolfo, \& Dellagnelo, 2012) attributed to the meaning of work by the interviewed drivers deserves special mention, especially when linked to the current Brazilian economic context and the unemployment situation. In this perspective, in the face of disappointment with the formal market, the meaning of work for these workers is supported by the financial return and the guarantee of survival. One can observe that disbelief in the labor market is not only in finding low wages but finding nothing, so that, as respondents say, to spend time and energy in competitive job selection processes, in addition to the low probability of hiring, generates financial loss from the hours not worked on 
the app. Some, however, keep sending resumes and trying to return to the formal market, hopeful that someday they might abandon this activity.

On other hand, in the Brazilian scenario, the desire to become an entrepreneur comes, historically, far ahead of that of making a career in a traditional company, losing only to the dreams of buying a house and traveling, as Lemos et al. (2017) point out. However, the disappointment with entrepreneurship, which was once a symbol of the liberation contained in the idea of being your own boss, is highlighted as one of the common antecedents to those interviewed who allude to freedom, autonomy, and flexibility of work through the app. This disappointment is a finding of the relevance of this research, considering the contextual reality by which these individuals sought to assign meaningfulness to the entrepreneurial work in the past (Lemos et al., 2017) and how, frustrated by the difficulties of this same reality, they started to do so adapted to contemporary conditions. This conclusion is supported by Rosso et al. (2010, p. 93), who advocate the use of a "comprehensive view", rather than the "examination of singular factors". In the scope of this study, therefore, it is not the disappointment that is highlighted, but the evidence that the desire for agency persisted among the workers even after the disappointment of the entrepreneurial attempt.

These sources of a meaning point to the predominance of the mechanisms of the "individuation" quadrant, evidently linked to the celebration of the "self" and to the construction of the "self-manager", characteristics typical of entrepreneurship. Rather than fading away with frustrated entrepreneurial activity, agency craving manifests itself in a new way in DLMs: through self-managed work focused on individual effort, and in which old troubles with staff and bureaucratic structure disappear. It differs from the reality of entrepreneurship; GE self-employment also differs from formal job submission: the individual gains control over work, the consent he needs is his own, and he sees his effort transformed into financial gain faster and with fewer intermediates. The working condition of the app drivers, therefore, does not fit in the old employee vs. employer dichotomy.

Thus, a certain exaltation of individuality is observed, where recognition by peers and superiors, a common search in formal jobs, is replaced by "the expansion in self-esteem through the perception of success and personal effectiveness" (Lemos et al., 2017, p. 113), depending only on the results themselves. In this sense, it is legitimate to assume that the autonomous, informal and individualized labor relations, characteristics of this new model, can, to a certain degree, result in the dismantling of cooperation among colleagues. Given this, it would be wrong to understand GE, centered on the "self", as a derivation of the sharing economy, in which the centrality of 
"others" underlies one of its pillars: strengthening the sense of community by strengthening social capital and increasing interpersonal (Parigi \& Cook, 2015) and generalized (Codagnone, Biagi, \& Abadi, 2016; Schor, 2014) trust.

The impossibility of assigning meaning to work beyond financial logic, however, can be a source of contradiction and suffering, as shown by the respondent Leandro, who do not see value in the social image of the driver's profession. In his opinion, people show prejudice when they ask if he is "just" a driver. Not seeing in the "others" dimension return beyond the economic one, Leandro turns to the "self" dimension and clings to the financial perspective. But even though he is well-paid ("I have graduated engineer friends who don't earn the same I do as a driver"), the job of a driver is not capable of promoting self-esteem and self-agreement for this young management graduate, "addicted" to courses on the internet about stock exchange operator work. To deal with the pressures, he does psychotherapy: "It's confusing. My head is always looping, you know?"

Such confusion and suffering point to the idea that, in fact, most people seek and need their work to have meaning (Leunissen, Sedikides, \& Wildschut, 2018). When a worker talks about meaning and meaningfulness of his work, however, he may be "referring to a complex amalgam of values derived from a number of different levels of experience", including the role he plays in family or community life and the identity that comes from being a part of a professional community (Baldry et al., 2007, p. 16), elements in which Leandro, for example, finds no support. From these unfilled gaps, the instrumental character is based on the temporary character of the activity, so that these workers, in some cases, see "being a driver" as temporary and not as a career or profession.

In view of such findings, it is emblematic to go back to Baldry et al. (2007, pp. 235-236): "Nobody wants their job to have no meaning, even if the primary or indeed only meaning is its economic support for home and family." Thus, the authors state, it is natural for people to "look for something beyond that, a sense of purpose or redemption, a source of challenge or enjoyment, or the ability of the work to confer or reinforce social identity or identities." So, through additional meanings, they seek to overcome the economic outlook of their labor, which would often give them nothing but monotony, stress, insecurity, and managerial self-discipline. This creation of sources of meaning does not only occur at the individual level: they find an echo in the collectivity (Baldry et al., 2007).

Thus, when the majority of respondents emphasize the temporary or complementary nature of the activity, one can even assume the production 
of meaning and meaningfulness for work as mechanisms of defense and coping to prevent illness, especially by the pressure caused by financial need, by self-demand and by not recognizing themselves as professional drivers. The words of Leandro ("Being a driver is not a life plan for anyone"), Leonardo ("my idea isn't to stay here for the rest of my life"), Guilherme ("it's not a business for life, app is not for life") and Geron ("I see this as a complement, you know? But for the rest of my life, I don't think so") sound like a route of emotional escape from the condition in which they are.

The meaning of work is immersed in "potential ambiguity", since workers, on one hand, try to deal with ideological and practical conditions of their "apparent disposability and short-term validity" and, on the other hand, are confronted with an "executive rhetoric" that tells them they have value to the company (Baldry et al., 2007, p. 10). Thus, in sharp contrast with all the positive aspects pointed out by the respondents in the search for the construction of the meaning of their work, the need for an expanded look is reinforced, capable of helping to unveil a movement that only begins to unfold. It follows, then, for the considerations that finalize this study.

\section{FINAL CONSIDERATIONS}

In this article, we aimed to investigate how app drivers are giving meaning to their work, taking as a theoretical assumption the model proposed by Rosso et al. (2010). From the speech of 37 interviewed drivers, we have identified elements that are in line with the four perspectives of the theoretical framework that arise through the intersections of the agency-communion and self-others dimensions, namely: unification, self-connection, individuation, and contribution. However, we observed a predominance towards the "agency" and the "self" extremities, synthesized under the "individuation" quadrant-in the opposite direction of the "unification" quadrant, at the intersection between the "others" and "communion" extremities, which better synthesizes the main SE values, as a sense of community and interpersonal trust.

This research contributes, firstly, to discussing meaning and meaningfulness of work from a theoretical model little used in Brazilian studies, since researches based on MOW perspective prevail (Spinelli-de-Sá $\&$ Lemos, 2015). When using the framework proposed by Rosso et al. (2010), we sought to overcome the mere distinction between meaning or meaningfulness, using both perspectives and seeking to situate them from 
the context (Bendassolli \& Gondim, 2014) in which the activity of app drivers develop. As a second contribution, this article proposes to intersect topics in general discussed alone, namely the study of the work world transformations and the construction of meanings and meaningfulness.

As a third contribution, this article addresses the concerns of international authors regarding the development of empirical researches that may help in analyzing the unfolding of the digital labor markets, especially their impact on workers. In fact, researches carried out by the researchers of this study, to investigate the national production on the subject, show that studies that approach the labor perspective in discussions about the sharing economy are still rare.

As research limitations, it is known that when interviewing drivers in the course of their work there are several influences that can impact the results. In addition to the natural distractions of driving and traffic, limiting interview time to the journey time has sometimes prevented further investigation of issues that merit further investigation. However, this same environment favors discussion, as it does not dislodge the workers from their environment, making them more comfortable with opinion. Since this study has an exploratory focus, some topics need to be deepened, for which suggestions for future studies are elaborated.

Noting that the production of meanings and meaningfulness of work are mediated and created by a wide variety of social contexts, Baldry et al. (2007) emphasize the need to understand it in a relationship in which both work factors (such as pay, intrinsic satisfaction, and career opportunities) and "non-work" life (such as family, class, gender, status, education, age group, structures and community values) are considered. Thus, as research suggestions, we suggest analyzing the theme from a greater stratification of respondents, aiming to use the heterogeneity of the field formed by app drivers to better understand it.

Morin (2001, p. 9) already pointed out that "the guiding principle of work organization is to modify behavior in such a way that workers are gradually led to developing positive attitudes" towards themselves, the tasks they perform and the organization in which they operate. An important consideration is the lack of consensus on the benefits and harms of the model: advocates perceive it as a way for people to use their free time in a flexible and autonomous way, allowing extra gains, greater freedom, and balance between life and work. In the pessimistic view, these currently deregulated labor markets are transvestite means for exploiting workers by reducing labor costs, where there are no benefits or social protection 
(Balaram et al., 2017; Codagnone, Abadie, \& Biagi, 2016). Thus, considering how recent the activity contemplated in this study is, in addition to the disruptive and diverse nature of the way the work is organized, we suggest the elaboration of longitudinal studies that can investigate possible changes in relation to the respondents' perception over time.

In addition, as Baldry et al. (2007) point out, the meaning, role, and importance that the work assumes are mediated by several commitments, demands, interests and orientations, so that workers of different sectors assign different meanings to work and have different sources and expressions of professional and personal identity. Thus, when investigating the DLMs just from the perspective of the app drivers, it remains open an investigation space. Examining workers of other activities could contribute to the broadening understanding of the phenomenon of the work world transformations.

Believing that it is impossible to exhaust this discussion in the brief pages presented here, it is understood that there are many developments and questions to be deepened. If the studies on SE, GE, and DLMs are booming, they have not yet been able to outline all possible developments. There are aspects that, while key to broaden the understanding of the phenomenon, lack further evidence. "After all, we are in the eye of the hurricane, immersed in changes we may not yet have the necessary distance to understand" (Lancman, 2011, 24). What is known, without a shadow of a doubt, is the resilience ability of workers, as the driver Jean says: "We're Brazilians, and we never give up".

\section{A BUSCA PELA AGÊNCIA: O SENTIDO DO TRABALHO PARA MOTORISTAS DE APLICATIVOS}

\section{RESUMO}

Objetivo: Este estudo objetiva investigar como motoristas de aplicativos de transporte estão atribuindo sentido ao seu trabalho, tomando como pressuposto teórico o modelo proposto por Rosso, Dekas \& Wrzesniewski (2010).

Originalidade/valor: Internacionalmente, é considerado baixo o volume de pesquisas empíricas envolvendo mercados laborais digitais. Nacionalmente, pesquisas no contexto da Economia Compartilhada 
raramente enfocam a perspectiva laboral. Apesar de ser fenômeno em crescimento, não foram encontrados estudos sobre a produção de sentidos e significados do trabalho por motoristas de aplicativos.

Design/metodologia/abordagem: De natureza qualitativa e exploratória, esta pesquisa foi realizada com 37 motoristas de aplicativos no período entre maio e setembro de 2017, em Porto Alegre (RS). Selecionados aleatoriamente, os entrevistados foram acionados para um percurso de trabalho pelo mecanismo de aplicativos de transporte privado de passageiros em seu ambiente laboral. O conteúdo das entrevistas foi categorizado e analisado a partir do framework de Rosso et al. (2010).

Resultados: Foram encontrados elementos que remetem a todos os quadrantes do modelo: "auto-conexão", "individualização", "contribuição" e "unificação". O sentido da atividade, entretanto, se expressa predominantemente no desejo, na busca e na valorização por agência, nos mecanismos de auto-eficácia e auto-gestão, em especial nas perspectivas financeira, de autonomia e flexibilidade. Esta pesquisa contribui ao interseccionar o estudo das transformações do mundo do trabalho e a construção de sentidos e significados, utilizando-se de um framework pouco utilizado nas pesquisas brasileiras. Além disso, colabora para ampliar o entendimento sobre a expansão dos mercados laborais digitais, em especial, nos seus impactos sobre os trabalhadores.

\section{PALAVRAS-CHAVE}

Sentido e significado do trabalho. Economia Compartilhada. Mercados Laborais digitais. Gig Economy. Motoristas de aplicativos.

\section{$\int$ REFERENCES}

Allan, B. A., Autin, K. L., \& Duffy, R. D. (2014). Examining social class and work meaning within the psychology of working framework. Journal of Career Assessment, 22 (4), 543-561. doi:10.1177/1069072713514811

Andrade, S. P. C. de, Tolfo, S. da R., \& Dellagnelo, E. H. L. (2012). Sentidos do trabalho e racionalidades instrumental e substantiva: Interfaces entre a Administração e a Psicologia. Revista de Administração Contemporânea, 16(2), 200-216. doi:10.1590/S1415-65552012000200003 
Balaram, B., Warden, J., \& Wallace-Stephens, F. (2017). Good gigs: a fairer future for the UK's gig economy. London, UK: RSA; Mangopay.

Baldry, C., Brain, P., Taylor, P., Hyman, J., Scholarios, D., Marks, A., Bunzel, D. (2007). The meaning of work in the new economy. Houndmills, Basingstoke, Hampshire, New York, NY: Palgrave Macmillan.

Bardin, L. (2016). Análise de conteúdo. São Paulo, SP: Edições 70.

Bendassolli, P. F., \& Gondim, S. M. G. (2014). Significados, sentidos e função psicológica do trabalho: Discutindo essa tríade conceitual e seus desafios metodológicos. Avances en Psicología Latinoamericana, 32(1), 131-147. doi:10.12804/apl32.1.2014.09

Benevides, T. M., Almeida, D. R., Cunha, E. A., \& Mendes, J. F. (2014). Sentidos do trabalho para os policiais militares do estado da Bahia: Uma primeira análise. Gestão \& Conexões, 3(2), 181-197.

Borchardt, P., \& Bianco, M. de F. (2016). Meanings of volunteer work: A study with members of a Lutheran institution. Revista de Administração Mackenzie, 17(5), 61-84. doi:10.1590/1678-69712016/administracao.v17 n5p61-84

Botsman, R., \& Rogers, R. (2011). O que émeué seu: Como o consumo colaborativo vai mudar o nosso mundo. Porto Alegre, RS: Bookman.

Brescia, R. H. (2016). Regulating the sharing economy: New and old insights into an oversight regime for the peer-to-peer economy. Nebraska Law Review, 95(1), 60. Retrieved from http://digitalcommons.unl.edu/nlr/ vol95/iss $1 / 4$

Cacciamali, M. C., Ribeiro, R., \& Macambira, J. (2011). Século XXI: Transformações e continuidades nas relações de trabalho. Fortaleza, CE: Instituto de Desenvolvimento do Trabalho; Banco do Nordeste do Brasil; Universidade de São Paulo.

Campos, M. de, \& Saraiva, L. A. S. (2014). O trabalho, suas representações e sentidos: Da demissão à recontratação de trabalhadores. Revista Economia $\mathcal{E}$ Gestão, v. 14, n. 36. doi:10.5752/P.1984-6606.2014v14n36p31

Carr, C. T., Hall, R. D., Mason, A. J., \& Varney, E. J. (2017). Cueing employability in the gig economy: Effects of task-relevant and taskirrelevant information on Fiverr. Management Communication Quarterly, 20. doi:10.1177/0893318916687397

Cattani, A. D. (2014). Trabalho: Horizonte 2021. Porto Alegre, RS: Escritos.

Cherry, M. A. (2016). Beyond misclassification: The digital transformation of work. Comparative Labor Law and Policy Journal, 37(3). 
Codagnone, C., Abadie, F., \& Biagi, F. (2016). The future of work in the "sharing economy": Market efficiency and equitable opportunities or unfair precarisation? JRC Science for Policy Report, 1-100. doi:10.2791/431485

Codagnone, C., Biagi, F., \& Abadie, F. (2016). The passions and the interests: Unpacking the "sharing economy". Science for Policy Report, 1-160. doi:10.27 91/474555

Concolatto, C. P., \& Oltramari, A. P. (2017). Relações de trabalho: Reflexões sobre suas transformações e permanências. Paper presented at the sixth meeting of Gestão de Pessoas e Relações de Trabalho, Curitiba, PR, Brazil.

Coyle, D. (2017). Precarious and productive work in the digital economy. National Institute Economic Review, 240, 5-14.

De-Stefano, V. (2017). The rise of the "just-in-time workforce": On-demand work, crowdwork and labour protection in the "gig-economy." Geneva, CH: ILO.

Deloitte (2017). Rewriting the rules for the igital Age. New York, NY: Deloitte University Press.

Donini, A., Forlivesi, M., Rota, A., \& Tullini, P. (2017). Towards collective protections for crowdworkers : Italy, Spain and France in the EU context. Transfer, 23(2), 207-223. doi:10.1177/1024258916688863

Donovan, S. A., Bradley, D. H., \& Shimabukuro, J. O. (2016). What does the gig economy mean for workers? Congressional Research Service, 1-20. Retrieved from https://fas.org/sgp/crs/misc/R44365.pdf

Eurofound and the International Labour Office. (2017). Working anytime, anywhere: The effects on the world of work. Eurofound (Vol. 1). Luxebourg, LUX; Geneva, CH: Publications Office of the European Union. doi:10.28 06/372726

Findlay, P., \& Thompson, P. (2017). Contemporary work: Its meanings and demands. Journal of Industrial Relations, 59(2), 122-138. doi:10.1177/0022 185616672251

Fleming, P. (2017). The human capital hoax: Work, debt and insecurity in the Era of Urbanization. Organization Studies, 38(5), 691-709. doi:/10.11 $77 / 0170840616686129$

Flick, U. (2009). Introdução à Pesquisa Qualitativa (3 ${ }^{\text {rd }}$ ed.). Porto Alegre, RS: Artmed.

Gil, A. C. (2010). Como elaborar projetos de pesquisa (5 ${ }^{\text {th }}$ ed.). São Paulo, SP: Atlas. Graham, M., \& Shaw, J. (2017). Towards a fairer Gig Economy. Meatspace Press. 
Kovács, I. (2002). As metamorfoses do emprego: Ilusões e problemas da sociedade da informação. Oeiras, PT: Celta.

Kovács, I. (2006). Emprego flexível em Portugal: Alguns resultados de um projeto de investigação. In V. Piccinini, L. Holzmann, I. Kovács, \& V. N. Guimarães (Eds.), O mosaico do trabalho na sociedade contemporânea: Persistências e inovações (pp. 23-46). Porto Alegre, RS: Editora da UFRGS.

Lancman, S. (2011). O mundo do trabalho e a psicodinâmica do trabalho. In S. Lancman, \& L. I. Sznelwar (Eds.), Christophe Dejours: da psicopatologia à psicodinâmica do trabalho ( ${ }^{\text {rd }}$ ed.). Rio de Janeiro, RS: Fiocruz.

Lemos, A. H., Cavazotte, F., \& Souza, D. O. S. (2017). De empregado a empresário: Mudanças no sentido do trabalho para empreendedores. Revista Pensamento Contemporâneo em Administração, 11 (5), 103-115.

Leunissen, J. M., Sedikides, C., \& Wildschut, T. (2018). Organizational nostalgia lowers turnover intentions by increasing work meaning: The moderating role of burnout. Journal of Occupational Health Psychology, 23 (1), 44-57. doi:10.1037/ocp0000059

Manyika, J., Lund, S., Bughin, J., Robinson, K., Mischke, J., \& Mahajan, D. (2016). Independent work: Choice, necessity, and the gig economy. New York, NY: McKinsey Global Institute.

Mocelin, D. G. (2015). Emprego e mudança tecnológica no Brasil. Porto Alegre, RS: Cirkula.

Morin, E. M. (2001). Os sentidos do trabalho. Revista de Administração de Empresas, 41 (3).

Murillo, D., Buckland, H., \& Val, E. (2017). When the sharing economy becomes neoliberalism on steroids: unravelling the controversies. Technological Forecasting and Social Change, 125, 66-76. doi:10.1016/j. techfore.2017.05.024

Nascimento, R. P., Costa, D. V. F., Salvá, M. N. R., Moura, R. G., \& Simão, L. A. S. (2016) "Trabalhar é manter-se vivo": Envelhecimento e sentido do trabalho para docentes do ensino superior. Sociedade, Contabilidade e Gestão 11(2), 118-138. doi:10.21446/scg_ufrj.v11i2.13382

Nyombi, C. (2015). A response to the challenges posed by the binary divide between employee and self-employed. International Journal of Law and Management, 57(1), 3-16. doi:10.1108/IJLMA-03-2013-0012

Parigi, P., \& Cook, K. (2015). Trust and Relationships in the Sharing Economy. Contexts, 14(1), 18-19. 
Pereira, E., \& Tolfo, S. (2016). Estudos sobre sentidos e significados do trabalho na psicologia: uma revisão das suas bases teórico-epistemológicas. Psicologia Argumento, 34(86), 302-317.

Pinto, L. B., Paula, A. V., Lobato, C. B. P., \& Boas, A. A. V. (2015). Sentidos do trabalho: Um estudo exploratório com trabalhadores do Polvilho em Minas Gerais. Revista Pretexto, 16(4), 65-81.

Rocha-de-Oliveira, S., \& Piccinini, V. C. (2011). Mercado de trabalho: Múltiplos (des)entendimentos. Revista de Administração Pública, 45(5), 1517-1538.

Rodrigues, A. L., Barrichello, A. \& Morin, E. M. (2016). Os sentidos do trabalho para profissionais de enfermagem: Um estudo multimétodos. Revista de Administração de Empresas, 56(2), 192-208. doi:10.1590/S0034759020160206

Rodrigues, A. L., Barrichello, A., Irigaray, H. A. R., Soares, D. R., \& Morin, E. M. (2017). O trabalho e seus sentidos: Um estudo com peritos criminais da Polícia Federal. Revista de Administração Pública, 51 (6), 1058-1084. doi:10.1590/0034-7612159318

Rohm, R. H. D., \& Lopes, N. F. (2015). O novo sentido do trabalho para o sujeito pós-moderno: uma abordagem crítica. Cadernos EBAPE.BR, 13(2), 332-345. doi:10.1590/1679-395117179

Rosso, B. D., Dekas, K. H., \& Wrzesniewski, A. (2010). On the meaning of work: A theoretical integration and review. Research in Organizational Behavior, 30, 91-127. doi:10.1016/j.riob.2010.09.001

Scholz, T. (2016). Cooperativismo de plataforma: Contestando a economia do compartilhamento corporativa. São Paulo: Editora Elefante, Autonomia Literária, \& Fundação Rosa Luxemburgo.

Schor, J. (2014). Debating the Sharing Economy. Great Transition Iniciative. Retrieved from http://greattransition.org/publication/debating-thesharing-economy

Silva, K. A. T., Borges, G. F., Mafra, F. L. N., \& Cappelle, M. C. A. (2013). Ser Prostituta: o sentido do trabalho moralmente inaceitável. Revista Eletrônica de Gestão Organizacional, 11 (2), 215-246.

Silva, K. A. T., \& Cappelle, M. C. A. (2015). Sentidos do trabalho apreendidos por meio de fatos marcantes na trajetória de mulheres prostitutas. Revista de Administração Mackenzie, 16(6), 19-47. doi:10.1590/1678-69712015/ administracao.v16n6p19-47 
Silva, K. A. T., \& Cappelle, M. C. A. (2017). O trabalho na prostituição de luxo: Análise dos sentidos produzidos por prostitutas em Belo Horizonte MG. Revista de Gestão Social e Ambiental, 23-39. doi:10.24857/rgsa. v0i0.1391

Silva, M. P., \& Simões, J. M. (2015). O estudo do sentido do trabalho: Contribuições e desafios para as organizações contemporâneas. Revista Capital Científico, 13(3). doi:10.5935/2177-4153.20150027

Siqueira, K., Martins da Silva, J., \& Angnes, J. (2017). “Cuidar de preso?!”: Os sentidos do trabalho para agentes penitenciários. Revista de Ciências da Administração, 19(48), 84-95.

Spinelli-de-Sá, J. G., \& Lemos, A. H. da C. (2015). Sentido do trabalho: Uma análise da produção científica brasileira. Paper presented at the XXXIX meeting of Anpad, Belo Horizonte, MG, Brazil.

Steger, M. F., Dik, B. J., \& Duffy, R. D. (2012). Measuring meaningful work: The work and meaning inventory (WAMI). Journal of Career Assessment, 20(3), 322-337. doi:10.1177/1069072711436160

Sundararajan, A. (2016). The Sharing Economy. Cambridge, MA: The MIT Press.

Todolí-Signes, A. (2017). The "gig economy": Employee, self-employed or the need for a special employment regulation? Transfer, 23(2), 193-205. doi:10.1177/1024258917701381

Tolfo, S. R., Coutinho, M. C., Almeida, A. R., Baasch, D., \& Cugnier, J. S. (2005). Revisitando abordagens sobre sentidos e significados do trabalho. In Fórum CRITEOS. Porto Alegre.

Tolfo, S. da R., \& Piccinini, V. (2007). Sentidos e significados do trabalho: Explorando conceitos, variáveis e estudos empíricos brasileiros. Psicologia E Sociedade, 19(1), 39-46. doi:10.1590/S0102-71822007000400007

Vilas Boas, A. A., \& Morin, E. M. (2016) Sentido do trabalho e fatores de qualidade de vida no trabalho: A percepção de professores brasileiros e canadenses. Revista Alcance, 23(3), 272-292. doi:10.14210/alcance.v23n3 


\section{) AUTHOR NOTE}

Marcia Cristiane Vaclavik, Programa de Pós-graduação em Administração, Universidade Federal do Rio Grande do Sul (UFGRS); Liana H. Pithan, Escola de Comércio, Comunicação e Artes, Pontifícia Universidade Católica do Rio Grande do Sul (PUCRS).

Marcia Cristiane Vaclavik is now PhD Student at Escola de Administração at Universidade Federal do Rio Grande do Sul (UFRGS); and Liana H. Pithan is now Master Student at Escola de Administração at Universidade Federal do Rio Grande do Sul (UFRGS).

Correspondence concerning this article should be addressed to Marcia Cristiane Vaclavik, Washington Luiz Street, 855, Centro Histórico, Porto Alegre, Rio Grande do Sul, Brazil, CEP 90010-460.

E-mail: mcvaclavik@gmail.com

\section{EDITORIAL BOARD}

Editor-in-chief

Silvio Popadiuk

Associated Editor

Andrea Rodrigues

Technical Support

Vitória Batista Santos Silva

\section{EDITORIAL PRODUCTION}

Publishing Coordination

Irina Migliari

Editorial Trainee

Maria Luiza Vanz

Copy Editor

Irina Migliari

\author{
Language Editor \\ Daniel Leão \\ Layout Designer \\ Emap \\ Graphic Designe \\ Libro
}

